\title{
Images of the Gentleman in Victorian Fiction
}

\author{
Mahmut Terci, PhD \\ Beder University, Tirana
}

Abstract

\begin{abstract}
The term 'gentleman' has been used in English culture by an enormous number of people loading varied meanings to its concept. The idea of the 'gentleman' has attracted many historians, philosophers, religious figures and writers. Countless comments have been uttered and a large number of studies have been written about it and probably many more will be published in the future. Who were or are called gentlemen then or now? What qualities are necessary for a person to be a gentleman? How does a historian, a philosopher, a social scientist, a religious figure or a writer define the term gentleman? In which period of history being a gentleman was fashionable? The complex mixture of qualities expected in a gentleman such as his 'birthright', 'education', 'wealth', 'income', 'vocation', 'civic responsibilities' and 'personal virtue' have made it difficult to pinpoint exact definition. Although it has been hard for everybody to pinpoint an exact definition for the term because of its connotations with 'masculinity', 'social class', 'manners', 'morality' and 'Englishness' we have brought varied views of critics, writers and important figures to observe their point of views. We need to see the gentleman's social position in the English gentry and his evolution from fifteenth century to nineteenth century. While the gentleman's chivalric qualities used to play important roles as well as his social status and wealth in the fifteenth and sixteenth centuries, the gentleman's manners and morals gained more importance in the coming up centuriesThe purpose of this paper is to offer a clearer picture of the concept of the gentleman especially in the Victorian times.
\end{abstract}

Keywords: gentleman, English gentleman, Victorian gentleman, gentry, gentility

\subsection{Introduction}

When the term first appeared in Chaucer's Canterbury Tales, it was used ironically to describe a 'verray, parfit, gentil knight' (qted in Pollard, 3-4). The chivalrous characteristics were the main focus in the connotation of the term. In the following centuries (the $16^{\text {th }}$ and $17^{\text {th) }}$, the 'gentlemen' were a social group in the English gentry just below the baronets, knights and esquires. Prestigious professions or wealth made the lower class people call the upper class social status as 'gentleman.' The developments in economy and sciences within the expanding of the English empire in the eighteenth and nineteenth centuries had a great influence on scientific, social and moral issues. The term was preferred to be used to envisage the manners of the people rather than class signification in the Victorian age. Conduct books were extremely popular in the nineteenth century. In the modern time the reputation of the concept has almost faded away, but to become a real 'gentle' and 'kind' man has never lost its importance.

Recent research on the concept of the gentleman has pointed out various definitions and interpretations of the term taking into consideration distinct approaches by writers, sociologists, historians, philosophers and religious figures. Not only have the varied perspectives on the concept of the gentleman by different people in different periods made it more difficult to pinpoint the term, but also the changes in the class system related to the expansion of the empire, those in the education system, in people's moral values and social behaviors have added a plurality of additional meanings to the word.

The Victorian age was the high time when the gentlemanliness used to see its rise and be considered almost like a religion due to its popularity.

\subsection{England in the Victorian Age}

The Victorian Age, whose name derived from Queen Victoria, who ruled the British Empire from 1837 to 1901, was actually the period comprised between 1830 and 1880. It is considered that the Victorian Age properly started in 1832 when the first of the Reform Bills were passed. According to George P. Landow, "it was the time when Britain saw great expansion of wealth, power and culture." (Landow, 1) While the era saw the stability, progress and social reforms, the great problems such as poverty, injustice and social unrest were the facts about the period of time. The new approaches from science and technology to religion, from literature and arts to ideology and politics, the Victorian society had great changes in their own 
era and had also great influences on the modern age today from the idea of invention to democracy, from feminism to socialism, from doubts in religious faith to the eccentric ideas of Darwin, Marx and Freud, and above all

...it was the age of paradox and power. The Catholicism of the Oxford movement, the Evangelical movement, the spread of the Broad Church, and the rise of Utilitarianism, socialism, Darwinism, and scientific Agnosticism, were all in their own ways characteristically Victorian; as were the prophetic writings of Carlyle and Ruskin, the criticism of Arnold, and the empirical prose of Darwin and Huxley; as were the fantasy of George MacDonald and the realism of George Eliot and George Bernard Shaw. (Landow,1)

Furthermore, Landow thinks what really makes Victorians Victorian is their sense of 'social responsibility' or 'social duty' and tries to prove his suggestion by giving examples from Tennyson who went to Spain to help insurgents and also urged the necessary of educating "the poor man before making him our master" to Mathew Arnold who refused to reprint his poem as his main character in it who kills himself - set a bad example for the public readers. (Landow, 1)

Drawing on Raymond Williams, Adina Ciugureanu gives a detail explanation of the key concepts; 'industry', 'democracy', 'class', 'art' and 'culture' of the age and states that the development of the five concepts is seminal to understand the Victorian Age as the century progressed in three directions: economy, society and culture (Ciugureanu, 13). Democracy, industrial development, political reforms, urbanization, loss of strong religious faith, education at public schools, scientific discoveries, development in people's understanding of morality and class notion, the financial improvements of middle class and people's lifestyles, from their reading to travelling, from their table manners to addressing people, from their writing letters to leisure activities such as hunting, playing cricket and swimming, they all had a various impact on literature. While Dickens's Hard Times, Carlyle's Chartism and E. Gaskell's North and South were associated with 'industrial novels', Darwin's scientific book the Origin of Species challenged the people's belief in God. And while W. Thackeray's Vanity Fair is a good example for the 'novel of manners', Dickens's A Tale of Two Cities is an example for 'historical novels' and his Great Expectations, which will be focused on in detail later, is a good example for 'humanitarian novels'. (Ciugureanu, 1416) In fact, there are more writers who have developed their own styles and admired by many Victorian and modern readers. In the following sub-chapters, some of the works of the Victorian novelists, whose approaches vary in terms of the gentleman they portrayed in their works, are analyzed in details.

When does the study of Victorian literature begin? According to G.K. Chesterton it was the period when the attacks on the Victorian rationalism started by various significant personalities. What were these attacks, then? For Chesterton, the first attack on Victorian rationalism, which held the centre, was the 'Oxford Movement' the second was 'Dickens' and the third one, was a group - Carlyle, Ruskin, Kingsley, Maurice and perhaps Tennyson - who tried to create a new romantic Protestantism. (Chesterton, 1) Moreover, in his other article, George P. Landow places the movements and currents in the Victorian age - in politics, literature, and culture - into four categories: 1. Progressive vs. Conservatives, 2. Radical Progressive vs. Tory Radical vs. Conservative, 3. Moral vs. Aesthetic, 4. Believers vs. Nonbelievers to explain the trends, tendencies, movements or loosely organized schools of Victorian thought. (Landow, 1)

The reason why we have mentioned all this information is to mirror the general sociological trends in Victorian history and culture. As the novel is one of the most important genres in Victorian fiction and as we have already suggested that 'the idea of the gentleman' was one of the important themes in Victorian novel, our next concentration will be first on the 'Victorian novel' and then on 'the idea of the gentleman in the Victorian novel'.

\subsection{The Victorian Novel}

The novel was the leading form of literature in the Victorian age. The heritage of the $18^{\text {th }}$ century with the changes and developments in politics, society and economy made the novel one of the main form of communication and education among social groups in the Victorian society. According to Adina Ciugureanu, "the novel becomes the vehicle of the social awareness of the whole period", and she explains the development of the novel as follows:

Basically, the development of the Victorian novel depends on the eighteenth-century heritage and is closely associated with different kinds of realism: Defoe's documentary concreteness, Richardson's sentimentalism, Fielding's and Smollett's picaresque features, Jane Austen's refined comedy of manners, Scott's revelation of historical causes and conditions. (Ciugureanu, 43) 
She also gives a special emphasis on the models seen in the novels, written by the eighteenth-century novelists, which become examples or role-models for the Victorian people. Taking the case further, she claims that "the Victorian novel became, in a sense, an epic." (Ciugureanu, 44) So, reminding the fact that "the plot is not necessary but the protagonist is" (Ciugureanu, 44), she states that the main character's struggling in the society becomes a kind of portrait in which the character's psychological motivations are explored. She concludes her point of view as "thus, the character becomes a rounded personality, a complete human being, with biological and educational history, with an economic, social, domestic and intellectual life of its own." (Ciugureanu, 44) As this paper focuses on the detailed analysis of the 'gentleman' in Victorian culture and its production, the 'Victorian novels', this fact, which has already been emphasized by A. Ciugureanu, takes an important place in shaping the general outlines about the idea of the 'gentleman' in Victorian culture.

Generally, the Victorian novels have long and complicated plots; the characters are analyzed in detail; the whole texture of events is explained in the final chapter and the omniscient narrator comments on the plot and distinguishes the right from the wrong. While the social and humanitarian themes were popular in the early Victorian novels - such as Charles Dickens's novels -, the theme of the persistence of Romantic and Gothic tradition and a psychological vein were popularized by the Brontë sisters and Stevenson in the Mid-Victorian time and the Late-Victorian novels were mainly about a scientific look at human behavior and discontent with values such as the novels written by Thomas Hardy and Oscar Wilde's literary creation. The Victorian novels appealed to the readers due to their realistic descriptions of the places, well-rounded middle-class characters and their problems in the society. Thus, the Victorian readers could easily recognize and associate the characters, places (mostly growing big industrial cities) and even the events in their own lives. Self-made personalities become role-model characters for the lower and middle class people. The readers were kept being laughed, cried and suspended thorough the professional patterns of 'love', 'humor', 'suspense', 'melodrama' and 'pathos'.

We have already traced the term 'gentleman' from Chaucer's 'vary parfit gentil knight' to John Ball's 'When Adam dalf (or delved) and Eve span, Who was then the gentleman', from the gentleman with the coat of arms in Shakespearean times to Newman's ideal portrait of the gentleman, and then from its metamorphosis (the moral and manner connotations of the term rather than its significance linked to birth, social rank or wealth) to the idea of the 'true gentleman' and got a conclusion that the term is so complex that it is hard to pinpoint its exact definition and it is still hard to understand what each person means or implies using this term. ${ }^{1}$

Now, we have reached the Victorian Age with its inheritance from the previous centuries. Before we follow the 'gentleman' through the perspectives of some significant Victorian novelists, the Victorian novels are categorized according to their types first. Then, the chosen popular novelists - Thackeray, Dickens and Trollope - from different backgrounds describe different perspectives of the 'gentleman' in their periods. Their detailed descriptions of the society and particularly the 'gentleman' give us clear ideas about the characteristics of the English society and the 'gentleman's position or its perception' in Victorian England.

Due to the great popularity of the 'novel' as a literary genre in the Victorian Age, the Due to the great popularity of the 'novel' as a literary genre in the Victorian Age, the period can be considered as the age of 'fiction' from a literary point of view. There was an enormous demand for literary works from the public and thousands of books - most of them appeared in periodicals and magazines in serialized forms - were published in this period. Dickens's The Pickwick Papers for example, reached a circulation of 40,000 by the end of its run in November 1837 (Mays, 17). Mays describes the relation between the periodicals and the novel publication, as follows:

Magazine serialization of new fiction began in the 1830 s, and by the 1840 s serials were a common feature of half-crown monthlies, but the real take-off of this format came in the 1850s and 1860s with the founding of weekly magazines such as Dickens's Household Words (1850-9) and All the Year Round (est. 1859), and of monthlies such as Macmillan's (est. 1859) and Smith, Elder's prestigious Cornhill (1860-1975), first edited by Thackeray. Designed for family reading, such magazines offered one or two illustrated serials by the best-known authors, plus a wealth of other material, for the same 1s. price previously demanded for a novel "part" alone. As a result, such magazines reached as many as 100,000 readers and became the initial publishing venue for many of the major works of Collins and Trollope, George Eliot and Elizabeth Gaskell. (Mays, 17)

\footnotetext{
${ }^{1}$ See Terci, M. The Gentleman and the British Cultural Space International Journal of Cross-Cultural Studies and Environmental Communication Volume.2 Issue.1, 2013 pp.43-54 
More interestingly, according to Kelly J. Mays's research based on Walter Besant's estimation in 1899, the number of English-speaking reading public jumps from 50,000 in 1830 to 120 million by the 1890s. (Mays, 22) Yet, Kelly thinks that "though such estimates are factually inaccurate, they reflect a view widely promulgated in 1890s." (Mays, 22)

Ciugureanu claims that "three requirements were crucial to turn the novels into a real success: be comical, be sentimental, and create suspense in each of the episodes published in magazines. (Ciugureanu, 43) Various types of novels developed during the Victorian Age and they can be categorized as the 'sensational novel', with a mixture of melodrama, complicated plot and mystery, the 'imaginative or romantic novel', like the works of Bronte sisters, the 'historical novel' like the works of Walter Scott, the 'fantastic novel', like Lewis Carrol's Alice in Wonderland, the 'social or humanitarian novel', like Dickens's Hard Times and Oliver Twist, the 'domestic or sentimental novel', like Catherine Sedgwick's New-England Tale. A different classification is also offered by Hilary Schor according to the class distinction developed in the Victorian Age.

...Hilary Schor distinguishes between (1) the novel of high society (the 'silver fork' novel); (2) the novels of lower-class and criminal life (the 'Newgate' novels); (3) the budding social-realist novel focusing on factory and industrial-urban life; and (4) the novels of middle-class (or 'domestic' realism). ${ }^{1}$ (Schor in Tucker, 325)

In the general sense, Victorian novels, whose authorial voices are rather strong, due to the moral and social responsibility they felt for the society (from the position of teaching and preaching) and whose readers are on the other hand usually passive (from the position of listening and learning), aimed to represent the life as it is in their fictional world which the readers accepted what they read real and responded both emotionally and rationally. As a result, "the Victorian novel becomes a means of educating people, of healing society, of advocating morality, and progress." (Ciugureanu, 47)

\subsection{The Idea of the 'Gentleman' in Victorian Culture}

The idea of the 'gentleman' appealed to the Victorians as the term which involved both social and moral connotations. On the one hand, the 'gentleman' possessed a social position in the traditional landed 'gentry' among the baronets, knights and squires; on the other hand, the moral values such as honor, respect, kindness, sweat-heartedness, generosity, faithfulness, trustworthiness were attached to the idea. Thus, the Victorian novelists' approaches to the idea were based on both social and moral connotations at the same time. As Robin Gilmour suggests that

Just as in society at large the gentlemanly idea exercised its fascination because it was neither a socially exclusive nor an entirely moralized concept, so too the novelists move naturally and easily between the moral and social attributes of gentlemanliness: they are never pinned down, as Richardson is in Sir Charles Grandison, to strictly moral formulation, and their novels better for it. (Gilmour, 12)

Gilmour makes a comparison between the eighteenth- and the nineteenth-century novels and finds Dickens's Great Expectations for example, more successful as the idea of the 'gentleman' is used in a more complex way. It is never strictly attached to its moral connotations only as it is done in Grandison, an eighteenth-century novel.

Were the Victorians themselves certain what a real gentleman looked like or what exactly the idea of the gentleman was? What were his essential characteristics? How long did it take to become a gentleman? Was one born a gentleman or did one become a gentleman? David Cody thinks that the concept of the nineteenth-century gentleman is very complex. He claims that members of the British aristocracy were gentlemen by right of birth (although it was also emphasized, paradoxically enough, that birth alone could not make a man a gentleman), while the new industrial and mercantile elites inevitably attempted to be designated as gentlemen as a natural consequence of their growing wealth and influence. Other Victorians - clergy belonging to the Church of England, army officers, members of the Parliament - were recognized as gentlemen by virtue of their occupations, while members of numerous other eminently respectable professions - engineers, for example - were not. Further, Cody states that, the Victorians eventually settled on a compromise. By the latter part of the century, it was almost universally accepted that the recipient of a traditional liberal education based largely on Latin at one of the elite public schools - Eton, Harrow, Rugby, and so on -would be recognized as a gentleman, no matter what his origins had been. (Cody, 1)

\footnotetext{
1 For details see Hilary Schor, "Fiction", in Herbert F. Tucker (ed.), A Companion to Victorian Literature, London: Blackwell, 1999, p.325.
} 
Notably, the idea of the 'gentleman' plays an important role in the construction of the English society and culture. Due to the elasticity of the social status of the 'gentleman', the lower and middle class society easily found a space for themselves when they got rich. Until the Victorian period, the courtesy books tried to fill the gap between classes in terms of the polite manners considered as behavioral obligations in the society. The novels took this responsibility in the Victorian age. Moreover, the increase in the number of successful and wealthy merchants, and in the number of the administrators including civil and military high officials - for the need of the expanding empire - for the colonies -, in addition the increase in the number of distinguished professionals from writers to journalists, from engineers to doctors, from lawyers to university professors, gave a great opportunity for the lower and middle class people to get into élite group in the social hierarchy. The wealth is shared by millions of people through trades, industrialism, and urbanization. The development in all the areas of life - from art and architecture to literature, from means of transportation to means of communication, from public schools to university education - gave millions of people opportunities to get a high level social status. The public schools, universities and especially the literary works such as periodicals, magazines and novels educated and enlightened the Victorians in a positive way that they became the ancestors of the modern trends and movements in science, art, philosophy and literature. Although Reform Acts had been passed by the government as a result of some social and political unrest, British people did not face a bloody revolution as the revolutions occurred in France and Russia. The 'new' 'gentlemen' once who once belonged to lower social backgrounds shared the wealth and the power of governing side by side with the old aristocrats and they did not need to fight. They struggled in a civilized manner in their fight to share the wealth and the power as a result of the moral influence of the idea of the 'gentleman'.

Robin Gilmour outlines the fundamental characteristics of the gentleman in his work, The Idea of the Gentleman in the Victorian Novel, as follows:

...the idea of the gentleman carried some of the best hopes as well as the deepest contradictions of Victorian experience; behind snobbery, the anxious debates about who did and did not qualify as a gentleman, the uneasy relationship to the aristocracy, there lies the struggle of a middle-class civilization to define itself and its values, a process in which the novelists were intimately and sympathetically involved. (Gilmour, 14)

Thus, the social and moral struggles of the Victorians look like the process of the birth of a modern nation. All the births involve pains, but the result makes everybody happy. It is high time to have a closer look on the works of some Victorian novelists and focus on how they described the 'gentleman', what qualities made a 'gentleman' gentleman, the difference between 'snobs' and 'fake gentlemen', the effects the social background had upon the gentleman: birth, descending from a noble family, environment, official and unofficial education, wealth and strength of character. Thus, some important Victorian novelists, who have reflected the idea of the 'gentleman' from different perspectives in their works as, for example W.M Thackeray, Charles Dickens, Anthony Trollope who are from different backgrounds and periods of Victorian age as well as their references of the concept in their works, are chosen here to obtain the whole picture of the image of the gentleman.

\subsection{The 'Gentleman' and the Victorian Novelists}

The novelists chosen for this research paper have significant importance for the history of the Victorian novel. The idea of the 'gentleman' is in the centre of their major works and they reflect the evolution and, at the same time, the devolution of the concept from the beginning of the Victorian period until the end of the $19^{\text {th }}$ century. These novelists', with varied backgrounds and different approaches to the concept of the 'gentleman', do not only mirror their own perspectives but they also mirror the Victorians' changing ideas about the concept in the course of time. While W.M Thackeray, who had come from an upper-class family, got his education like a 'gentleman', lived like a 'snob' for a while in his youth, used the language of a 'gentleman' and wrote about the 'snobs' and 'gentlemen' in his works, reflects the lives of the aristocrats much better, Charles Dickens, who had a humble origin, got his education with great difficulty, had to live and work in poor conditions at a factory when he was young, reflects the lives of the poor, at times of noble origin, and their struggle to accede to a better condition in life. Dickens's protagonists are usually orphans and they ambitiously struggle to become 'gentlemen' and to get 'respectability' in their lives. A. Trollope, who had an aristocrat background, preferred to use his characters strictly according to their positions including the 'gentleman' in the traditional hierarchy of the 'gentry'. Supportive ideas and comments, which have to be mentioned to prove these arguments, find their place in the following sub-chapters. 


\subsubsection{The gentleman with William Makepeace Thackeray}

W. M. Thackeray was the person who gave the word 'snob' its modern sense to the English vocabulary. As his friend James Hannay wrote, 'Thackeray was a well-born, well-bred and well-educated gentleman,' being labeled by his contemporaries as 'the novelist as gentleman'". (Gilmour, 37)

Although Thackeray inherits 17,000 pounds from his parents, this fortune is lost through his addiction to gambling, in two ill-fated investments in periodicals - namely the Constitutional and the National Standard - and most of it through the failure of an Indian bank. The financial problem forces him to find a job and he starts to work as a journalist for Fraser's Magazine, The Morning Chronicle, New Monthly Magazine and The Times. His satires about English snobbery in Punch attract the public attention. Robert Fletcher writes that "before the success of Vanity Fair, Thackeray worked as a free-lance journalist for about ten years, publishing literary criticism, art criticism, topical articles, and fiction either anonymously or under a number of comic pseudonyms." (Fletcher) ${ }^{1}$ With Vanity Fair, Thackeray has a name that gains the public notice and professional reviews appear in journals such as the Edinburgh Review. The success and reputation continues with the publications of his later novels, yet his fame had been established with the introduction of the 'snob' as a major character in fiction.

His views on the idea of the 'gentleman' were complex, because, on the one hand, his gentlemanly status already got its shape through his noble birth, aristocrat environment and gentlemanly education and, on the other hand, there were severely attacks, such as criticisms in the publications, on the idea of the 'gentleman of birth' and the 'gentleman of rank'. The 'gentleman of moral' or the 'gentleman of manners' was gaining popularity among the Victorians at that time. It seems that he had to keep the balance between these groups and that is one of the reasons why he had a more complex approach to the concept of the 'gentleman'. Another reason for his ambivalent manner is the period he lived. He was described "with one foot 'in the era of later Georges' and the other in the Victorian period: so balanced, he was uniquely well placed to interpret for his own generation the transition from Regency to Victorian which they had lived through." (Gilmour, 40) Gilmour also interprets Thackeray's complex attitude as follows:

Thackeray is peculiarly the novelist of the period $1815-1845$, and it is against the background - the background of dandyism, the fashionable novel, the beginning of the middle-class assault on aristocratic privilege - that his redefinition of gentlemanliness needs to be seen. He understood better than any of his contemporaries that the flamboyant Regency and its long aftermath had been the nursery of the Victorian middle classes, and in novels like Vanity Fair and Pendennis he portrays the interaction between the self-confident worldliness of the old order and angular, domesticated morality of the new, struggling to define and assert itself in the early decades of the nineteenth century. (Gilmour, 40)

Thackeray's two different attitudes can be easily seen in his works. For example, he writes about the readers' feelings in The Second Funeral Napoleon (1841) as follows:

In the matter of gentleman, democrats cry, 'Pshaw! Give us one of nature's gentlemen, and hang your aristocrats.' And so, indeed, nature does make some gentleman - a few here and there. But art makes most. Good birth, that is, good, handsome, well-formed fathers and mothers, nice cleanly nursery maids, good meals, good physicians, good education, few cares, pleasant easy habits of life, and luxuries not too great or enervating, but only refining - a course of these going on for a few generations are the best gentleman-makers in the world, and beat nature hollow. (qted in Gilmour, 42)

So, the gentleman is connected to the idea of democracy as an opposition to aristocracy. At the end of The Four Georges (1861), Thackeray writes his famous rhetorical moralizing of the 'gentleman' as "what is to be gentleman? Is it to have lofty aims, to lead a pure life, to keep your honor virgin...?" (Gilmour, 42) Gilmour also states that "the two attitudes can be found at all stages of his career, but the hostile one predominates in the early writings up to Vanity Fair." (Gilmour, 42)

Before we proceed to analyze how Thackeray portrays his fictional characters in detail, it is important to mention a few characteristics of his writing style. Ciugureanu emphasizes the facts that "Thackeray's manipulation of character often recalls earlier, satiric modes, where the character is only a functional and typological being. The writer's apprenticeship in journalism and burlesque makes him witty, satirical, and at times even cynical. Thackeray's realism is the realism of critical attitude, which is mainly anti-heroic (e.g. the Waterloo scenes in Vanity Fair), and censors the excitement of dramatic illusion. His main themes are the corruption of values, the mean admiration of means things, the exposure of false heroism,

${ }_{1}^{1}$ See Robert Fletcher William, Makepeace Thackeray: A Brief Biography http://www.victorianweb.org/authors/wmt/wmtbio.html 
in particular the reputed heroism fostered by historical legends." (Ciugureanu, 49) In his article on Thackeray, W. E. Henley writes about Thackeray's writing style as follows:

Thus the two sects: the sect of them that are with Thackeray and the sect of them those are against him. Where both agree is in the fact of Thackeray's pre-eminence as a writer of English and the master of one of the finest prose styles in literature. His manner is the perfection of conversational writing. Graceful yet vigorous; adorably artificial yet incomparably sound; touched with modishness yet informed with distinction; easily and happily rhythmical yet full of colour and quick with malice and with meaning; instinct with urbanity and instinct with charm - it is a type of high-bred English, a climax of literary art. (Henley, 1)

Keeping these considerations in mind, mainly his genius and ability in writing, his anti-heroic characters, his satiric and cynical style, his dual and complex attitudes due to his aristocratic background as well as his transition from Regency to the Victorian period, we will focus on the works in which Thackeray portrays the gentleman. Thackeray attacks the eighteenth-century stereotype of the gentleman, who used to be considered as a gambling, drinking, dueling and philandering gentleman, in his early works with Galgenstein in Catherine (1839-40), Brandon in A Shabby Genteel Story (1840) and Barry in Memoirs of Barry Lyndon (1844). The following lines taken from Catherine illustrates the characteristics of gentleman-rogue which Thackeray satires.

And so he had the reputation of being a gentleman, not only wealthy, but discreet. In truth, it was almost a pity that worthy Brock had not been a gentleman born; in which case, doubtless, he would have lived and died as became his station; for he spent his money like a gentleman, he loved women like a gentleman, he would fight like a gentleman, he gambled and got drunk like a gentleman. (Thackeray, Catherina) ${ }^{1}$

The main character in Barry Lydon, the hero has a noble birth, gets a good breeding and education, excels in fencing, dancing and shooting, but kills Captain Quinn for his destroyed honor, runs away and has lots of adventures including his joining the army in the war time. He behaves like a 'gentleman,', drinks like a gentleman ('I drank my mother's health that night in a bumper and lived like a gentleman whilst the money lasted,' (Thackeray, Barry Lyndon) 2, gambles like a gentleman; 'Yet, if I could find myself in an honourable post, and with an assured maintenance, I would never, except for amusement, such as every gentleman must have, touch a card again.' ${ }^{3}$. He is also described to duel like a gentleman and more than that he shapes his own life according to the revenge code. He was about to pay a visit to his lady mother at Bath, when he recognized the well-known face of Mr. Barry Lyndon, in spite of the modest disguise which that gentleman wore, and revenged upon his person the insults of former days. ${ }^{4}$ With this book, Thackeray mocks the old manners of the gentlemanly behaviors and ironically portrays the eighteenth-century through the narrator who represents 'gentlemanly' attitudes such as killing for honor, gambling, dueling, drinking, philandering and even living for revenge. Also, we had better note Gilmour's idea about Thackeray's first works:

Certainly Thackeray's early writing is markedly anti-aristocratic: his noblemen are either rascals or nincompoops, and his middle-class characters are mocked for allowing themselves to be taken in by the mystique aristocracy. (Gilmour, 43)

Thackeray's The Book of Snobs (1848), which was the collection of his fifty-three weekly installments, appeared in Punch entitled "The Snobs of England, by one of themselves" between 1846 and 1847. The book did not only bring fame for Thackeray, but it also gave a vivid picture of the Victorian society 'which no other writer, not even Dickens, had grasped so comprehensively - the hectic struggle for social position in a society rendered volatile by the influx of new money and ambition.' (Gilmour, 45) The word 'snob' took its place in the English vocabulary as "the one who blatantly imitates, fawningly admires, or vulgarly seeks association with those regarded as social superiors" 5 but Thackeray himself defined the word as "the one who meanly admires the mean things." 6 His vague definition never pleased anyone though it encompasses the meaning quite well. While everybody had been expecting the word 'snob' referred to the people 'among the lower class', he contended that 'an immense percentage of Snobs I believe is to be found in every rank of this mortal life.' (qted in Ray,

\footnotetext{
${ }_{1}$ See W. M. Thackeray, Catherina, http://www.victorianweb.org/history/gentleman.html

${ }^{2}$ See W. M. Thackeray, Barry Lyndon, http://www.gutenberg.org/files/4558/4558-h/4558-h.htm

$3 / d$.

${ }^{4} / d$.

5 See http://www.merriam-webster.com/dictionary/snob

${ }^{6}$ See http://ebooks.adelaide.edu.au/t/thackeray/william_makepeace/snobs/chapter2.html
} 
22-23) The book enables us to see how Thackeray envisages snobbery, which is a subversion of the concept of gentlemanliness. Gilmour concludes his views about the book as follows:

The Book of Snobs shows Thackeray's awareness of the process of which money is 'washed into estates, and woods, and castles, and town mansions', but only in Vanity Fair is the awareness integrated with a narrator who can command and orchestrate the panorama of English social life that the Snob papers intimate but never quite achieve. (Gilmour, 47-8)

With the success of Vanity Fair, Thackeray's reputation was made permanent. Several reasons are put forward for its success as it got an appreciative review in the Edinburgh Review by Hayward, in which he said, judging by what had been already published, 'Vanity Fair is as sure of immortality as ninety-nine hundredths of modern novels are sure of annihilation;' (qted in Jr. Payne, 437-456) According to Thackeray himself, the reason for its success was the publication of his Christmas book Mrs. Perkyn's Ball. But the most probable explanation is that Thackeray's unusual, artistic, realistic style that he used in his works made it appealed by the Victorian readers. It is unusual because there are no exact heroes or heroines; as the Victorian critic, E. S. Dallas, described it 'Novel without a Hero.' The main characters are realistic and ordinary people, not exactly protagonists. It was the period of time when snobs began to appear in all areas of social life - no matter from which class - . His satiric language had an impact on the Victorian readers. Aftermath of the 'Victorian wars' - I mean the economical, political, philosophical and social struggles in the Victorian period - all the changes in the 'melting pot', formed the seeds of the modern nation which had a deep impact in all over the world. There was a great increase in the amount of readers in various tastes. His cynical and satirical tones in his language about the play and its puppets attracted a lot of admirers. Another important reason why Thackeray got his permanent reputation is that, the female characters in his novels - although they were not heroines - appealed to many readers as they reflected the realistic dimension of the Victorian society in this period. The reason why he used mostly humor and satire in his works is explained by L. W. Payne Jr. as follows;

He saw the hollowness and pretense of the outside show, and, like a true knight, took up his lance and boldly advanced to attack. "Such people there are," he writes in Vanity Fair," "living and flourishing in the world - faithless, hopeless, charitiless; let us have them, dear friends, with might and main. Some there are, and very successful, too, mere quacks and fools; and it was to combat such as these, no doubt, that laughter was made." Here we have the clue to his satirical view of life. (Payne, 449)

Payne Jr. also has a very interesting idea that all of Thackeray's novels could be placed under the general title of 'Vanity Fair' with the exception of Henry Esmond. He thinks that "in fact, Vanity Fair is unquestionably the greatest of his books. The other, with single exception named above, are but the fuller development of the principles, methods and thoughts laid down in the first great work." (Payne, 450)

In Vanity Fair, Thackeray chooses two female characters, named Becky Sharp and Amelia Sedley, who are close friends but quite different from each other in terms of their behaviors, points of views and ambitions. While the term 'sharp' symbolizes Becky's attractiveness, intelligence and crazy ambitions, the term 'sedley' implies Amelia's future sadly experiences, hardship and endurance. While Amelia lives for the affections of home and motherhood, Becky ambitiously tries to reach the 'pinnacle glory' at any cost. The whole story is set up over these characters. Becky, who is very clever ambitious and at the same time very attractive, is from a lower class, and is very enthusiastic to go into and be accepted by the aristocracy. She represents a social climber who uses all her qualities - such as her intelligence, her beauty, her singing ability and her speaking a foreign language - and all the chances to reach the top of the society. Although Becky, who dominates the first half of the novel, has a lot of faults - from her secret marriage to not taking care of her own son but she plays an important role in Amelia's marriage with William Dobbin in the end who is the closest character to be a real gentleman. As Adina Ciugureanu suggests that "Thackeray portrays the world he knows best. The evils of self-interest, of parasitism, and of snobbery release in him a detached ferocity." (Ciugureanu, 53) She also claims that

There are no positive characters in the novel. The aristocracy to whom the writer himself belonged, is depicted as hypocritical, not really well-bred, often mean (Sit Pitt), dirty, illiterate (Rawdon's letters), and brutal (Sir Pitt, Lord Steyne). (Ciugureanu, 53)

In an environment like this, the only way - and the best way according to Thackeray - is to laugh at them. A. Ciugureanu continues as follow: 
Thackeray laughed at almost everything: at the attempts of mothers marry their daughters to rich suitors, at the frantic effort of ageing ladies to appear youthful, at the hypocrisy of clergymen and their energetic and ambitious wives, at the tribute demanded by the poorer members of the family by their wealthier relations, at the paramount importance of money and the folly to which men and women stoop to get it. (Ciugureanu, 53)

That's why Thackeray mocks the snobbishness thorough the adventures of Becky and that's why with the help of the puppets he created, he laughs at them and makes the snobbish people be laughed at. In this way, probably, Thackeray takes his revenge from them. Yet, the realistic characters and the plot, besides Thackeray's ironical style mirror the Victorian age. Moreover, his mocking snobbishness draws the attention to the distinction between the snob and the gentleman.

\subsubsection{Charles Dickens and the idea of the gentleman}

Unlike Austen, Thackeray and Trollope, Charles Dickens did not have an aristocrat family and besides that for a while his father had to go to the prison as a result of his debts. In this period little Charles had to work in a blacking factory. Although some critics argued that Dickens could not describe a 'gentleman' as a result of his being an outsider to the life of the 'gentlemen', Gilmour suggests that "his ability to see the gentleman 'from the outside', as Chesterton recognized, gave him an insight into the Victorian pursuit of gentility, and the role of the gentleman in the structure of nineteenth century society, which a born insider like Thackeray could never have." (Gilmour, 107) Therefore, while Thackeray's gentlemen are very close to the aristocrats, Dickens's gentlemen are mostly self-made and closer to the lower class. Gilmour points out this fact as follows:

Dickens is concerned with the lower reaches of the middle class in its most anxious phase of self-definition, struggling out of trade and domestic services and clerical work into the sunshine of respectability.' (Gilmour, 106)

The hard life he had to endure developed his character in a way that, he became the voice of the people who had never been noticed and valued at all. He directly saw and lived the social injustices and became one of the novelists who used the hard life of the people as a subject in his works. Due to his social consciousness, his works attracted the public attention to the social problems such as poverty, poor conditions at workhouses - as in Oliver Twist - and factories - as in Hard Times, poor educational system - as in Nicholas Nickleby, the increase in crimes in big cities - as in Oliver Twist - and, more importantly, the injustice suffered by the lower class people who tried to obtain respectability by becoming gentlemen or ladies - as in Great Expectations and David Copperfield -. This point, which will be discussed in detail in the following chapters, is very important because Dickens portrayed the gentleman in his novels and they all have specific purposes and implications in the plot. What we emphasize in this sub-chapter is that, as a Victorian novelist, Charles Dickens developed the concept of the 'gentleman,' by enlarging its meaning, in most of his novels.

While in Great Expectations the main theme is Pip's struggle to become a gentleman and his understanding of the true gentility in Joe's character and attitudes, Oliver's nobility in Oliver Twist, which is found out in the end, is attached to idea of the gentleman in Dickens's early novel. Dickens praises the old gentleman, Mr. Brownlow, and Rose for their possessing gentle, kind, pure hearts and good natures, but he punishes the fake gentleman such as Mr. Bumble, for his being selfish, Fagin and Sikes for their unkind manners, cruelty and their murderous drives.

In Hard Times the fake gentlemen, such as Mr. Gradgrind - the man of facts and calculations - and Mr. Bounderby - the self-made rich but boastful man, are brought forward by Dickens with a view to criticizing the education given to the children and to satirizing the attitudes of the employers towards their employees in the industrial era. Nevertheless, in Nicholas Nickleby the disgusting manners and cruel behavior of Mr. Squeer squeeze the school children using physical and verbal violence. Mr. Gradgrind grinds the hopes and dreams of the children, even of his own, by using wrong methodology and ignoring children's psychological growth. As a result, Mr. Grandgrind's son, Tom, becomes a snob who drinks, gambles and spends his money extravagantly.

Unlike Aunt Betsey Trotwood, in David Copperfield, who becomes the shelter and sponsor for David in his later life, Uncle Ralph Nickleby, in Nicholas Nickleby, never gives a sincere help to his nephew, Nicholas. Although Ralph Nickleby is a rich person and he inherits the same blood, Dickens points out the fact that sometimes the noble blood is not enough for a man in his becoming a true gentleman. We also notice that Dickens uses the old traditional dueling of the two gentlemen, Hawk and Verisopht, as the result of ungentlemanly and rude behavior to a lady (Kate). 
Mr. Murdestone, in David Copperfield, may be seen as a fake, devious gentleman who is perceived like a murderer by David. His rude and cruel attitudes as well as his humiliating tone in the use of language towards David results in David's sending off to a boarding school and then in his working in a factory, albeit his very young age. At school, Steerforth becomes his close school friend and Mr. Micawber, David's first landlord, becomes a close family member. While the snob, Steerforth, seduces and dishonors Little Emily, who is David's first childhood love and Pegotty's orphaned niece, Mr. Micawber's assistance reveals Uriah Heep's misdeeds to Mr. Wickfield and migrates to Australia for a better life. Mr. Pegotty is another gentle person with a humble origin, attracts the admiration of the readers for his search of Little Emily and his dedication to leave everything behind her to start a new life in Australia. After getting rid of the Murdestones with the help of his Aunt Betsey, in his later period of his life, David comes across another person of humble origin, Uriah Heep, but unlike Mr. Pegotty, he betrays Mr. Wickfield secretly getting control of his business and wealth in order to allegedly become a gentleman and get married to Wickfield's daughter, Agnes. All his misdeeds and evil plans are revealed with the help of Mr. Micawber. He is also another interesting character who, like Dickens's own father, shares the fate of being sent to prison because of his debts. Yet, Mrs. Micawber is described as a most significant lady, who supports her husband in his hard times and shares all the difficulties they have to suffer.

In Great Expectations, the main character, Philip Pirrip, nicknamed Pip, becomes involved with various people belonging to different social classes. As an orphan child, Pip first finds himself with his sister and her husband, the blacksmith Joe. At first, Pip is ashamed of Joe's lack of education. Pip wishes that Joe could teach him the correct names for the card game, when he is young, and Joe's awkward manners as a result of his lack of knowledge in gentlemanly attitudes among the upper class-people make Pip behave in a snobbish way. Nevertheless, at the end of the novel, Pip realizes (and this is also the most important point in Dickens's perspective on the idea of the gentleman) that Joe is the true gentleman. In her study Victorian Selves, Adina Ciugureanu points out this fact as follows:

\section{... he [Pip] eventually understands the meaning of the word 'gentleman' which he applies}

to Joe when he addresses him as "this gentle Christian man" (Ch. 57). So money, education, good manners, and social position are worth very little outside Christian moral values. The ultimate achievement of a man who calls himself a gentleman in Victorian society is therefore, being a 'gentle man'. (Ciugureanu, 65)

Other true gentlemen who should be mentioned are Magwitch and Herbert. Magwitch, the convict, becomes Pip's secret benefactor and when he finds out that he is also the father of his Estella, his lige-long love, he assists him in his attempt to secretly leave the country. Magwitch dies happily when he sees Pip, the gentleman, that he has in a way 'created'. Herbert Pocket, who once had a fight with Pip at Satis House during his visits to Miss. Havisham, teaches Pip the art of 'gentlemanly' behavior from table manners to the polite manners in the public life when Pip stays in London. According to Ciugureanu,

Herbert teaches Pip elegant table manners, but he reminds him and the readers that they are meaningless unless they are grounded on moral principles. One cannot be "a true gentleman in manner" unless one is, according to Herbert's father "a true gentleman at heart" (Ch.22) (Ciugureanu, 64)

Pip has a great inner struggle with his conscience as a result of his ambition to become a gentleman. Dickens portrays his own perception about the idea of the gentleman through the progress of his main character, Pip, from snobbery to gentlemanliness.

\subsubsection{Anthony Trollope and the gentleman}

Anthony Trollope, who tried to describe the Victorian period realistically and also used the idea of the gentleman in his works, is another important writer who should be mentioned. When he is compared with Thackeray and Dickens, he did not face directly the growing pains of the early Victorian as the concept was under severe influences of the aristocratic insolence and the moralized gentry. Although the idea of the gentleman was central in his works, his readers might have had some problems with his understanding of the concept as a result of his hesitation to give his own definition to the term 'gentleman'. According to Gilmour

his notorious reluctance to say what he meant by a gentleman, which is sometimes taken as a sign of his confusion, implies just the reverse: he knew, or thought he knew, very well what a gentleman was, and his refusal to spell it out came partly 
from a feeling that gentlemen should not be too specific on such matters, and partly, I think, from a correct suspicion that many of his readers would be shocked to learn how very inegalitarian and unprogressive his concept was. (Gilmour, 149)

Why he shrank to give a definition of the term 'gentleman' could be seen, perhaps, in his autobiography. Rather skeptical about fame in his life and about the seriousness with which his contemporaries might consider his own views on the gentleman, Trollope wrote the following:

As what I now write will certainly never be read till I am dead, I may dare to say what no one now does dare to say in print - though some of us whisper it occasionally into our friends' ears - there are places in life which can hardly be well filled except by 'Gentlemen.' The word is one the use of which almost subjects one to ignominy. If I say that a judge should be a gentleman, or a bishop, I am met with a scornful allusion to "nature's gentlemen." Were I to make such an assertion with reference to the House of Commons, nothing that I ever said again would receive the slightest attention. A man in public life could not do himself a greater injury than by saying in public that the commissions in the army or navy, or berths in the civil service, should be given exclusively to gentlemen. He would be defied to define the term, - and would fail should he attempt to do so. But he would know what he meant, and so very probably, would they who defied him. It may be that the son of the butcher of the village shall become as well fitted for employments requiring gentle culture as the son of the parson. Such is often the case. When such is the case, no one has been more prone to give the butcher's son all the welcome he has merited than I myself; but the chances are greatly in favor of the parson's son. The gates of the one class should be open to the other; but neither to the one class nor to the other can good be done by declaring that there are no gates, no barrier, and no difference. The system of competitive examination is, I think, based on a supposition that there is no difference. (Trollope, 34-35)

This passage reveals that Trollope was highly conservative in his understating of gentlemanliness and was relatively unaffected by the modernizing tendencies which appeared in the Victorian period. He considers gentlemanliness as a rank but "he nowhere states that the gentleman is superior to the good and honest man who is not a gentleman, only that he is different." (Gilmour, 151) Thus, Gilmour thinks that "It is this honest realism, coupled with his lack of fuss about the gentleman, which makes Trollope seem a much less snobbish writer than Thackeray, although the latter's social analysis is a good deal more radical writer. The realism and the lack of fuss are of course related in Trollope, and derive from the fact that, unlike Dickens and Thackeray, he had an intimate understanding of the landed order in Victorian society." (Gilmour, 151)

The gentlemen in his works are mostly 'country gentlemen and squires'. He is quite strict in using the terms related to the landed gentry as a result of his family background and his thirty-three years spent as a postal surveyor in Ireland. He had an aristocrat background, his father Thomas Anthony finished New College at Oxford, became a lawyer and also tried to seek his fortune in farming but unfortunately failed in both jobs. As soon as young Anthony could hold the pen, his father "taught him the points to be aimed at in letter-writing - clearness, conciseness, abstinence from the repetition of words or ideas, and the non-introduction of any unnecessary or irrelevant matter" (Escott, 19-20). As for his mother, she was "a far more cultivated woman than might be supposed from her books. Proud, as well as fond, of all her boys, she taught them of an evening enough French, German, and Italian to speak and write these languages correctly, as well as understand them when spoken, without difficulty, and converse in them with ease." (Escott, 20)

Anthony Trollope had a difficult childhood due to his father's unsuccessful attempts in business. In his autobiography, he states that "My schoolfellows, of course, knew that it was so, and I became a pariah. It is the nature of boys to be cruel. I have sometimes doubted whether among each other they do usually suffer much, one from the other's cruelty; but I suffered horribly!" (Trollope, 11) Although he got his education at Harrow and Winchester among the other rich boys, the poverty the family suffered formed a different character of him. Unlike Thackeray, who had extravagant expenses in gambling, drinking and a lavish lifestyle in his youth, Trollope had to struggle financially in his early years of his youth. After his father's death, his mother traveled to America to look after her children in business, but she also failed. Returning to England she gained success with her book entitled Domestic Manners of the Americans. She was fifty-two at that time and she wrote until seventy-six to support her family through writing.

When Anthony Trollope was nineteen, he got a job as a clerk in the post office and seven years later he became a postal surveyor in Ireland spending thirty-three years in this job. He used this experience in many novels. Although he was criticized for his admitting that he had written for money, his Barsetshire novels, whose stories were set in the imaginary English country of Barsetshire, were the first serial fiction in English literature. He established his reputation as a writer with 
his fourth novel, The Warden (1855). Having read this work her mother said that "Of this, you owe nothing to me, and yet I have observed nothing like it in others of your period." (Escott, 32-33) In other words, she recognized her own teaching of précis writing, but also her son's obvious talent. With his own words, Trollope described his published works as a "series of novels of which Barchester, with its bishops, deans, and archdeacon, was the central side." (Trollope, 74-75) Although Trollope never lived in any cathedral city, except London, he explained the reason why he had chosen the story of clergymen in these series as an effort of his moral consciousness. Being a clergyman was also considered a gentleman's profession at that time. Trollope reflects some of his thoughts about the idea of the gentleman in terms of his profession and his social status through Miss Marrable's thoughts in The Vicar of Bullhampton (1870) as follows:

Miss Marrable thought a good deal about blood. She was one of those ladies, - now few in number- who within their heart of hearts conceive that money gives no title to social distinction, let the amount of money be ever so great, and its source ever so stainless. Rank to her was a thing quite assured and ascertained... She had an idea that the son of a gentleman, if he intended to maintain his rank as a gentleman, should earn his income as a clergyman, or as a barrister, or as a soldier, or as a sailor. Those were the professions intended for gentlemen. (Trollope, ch.9)

The people, who had those professions mentioned above, were considered easily 'gentlemen' as their income was sufficient not only by Miss Marrable but also by some writers from Fielding and Richardson to Thackeray and Dickens. Being a civil servant himself, Trollope finds this approach out of date and more importantly unlike Thackeray and Dickens, Trollope thinks that money itself should not play a great role in someone's endeavor in becoming a gentleman.

The strongest point in her character was her contempt of money. Not that she had any objection to it, or would at all have turned up her nose at another hundred a year had anybody left to her such an accession of income; but that in real truth she never measured herself by what she possessed, or others by what they possessed. (Trollope, ch.9)

Gilmour points out the fact that "for Trollope this is the heart of matter. Whereas Dickens and Thackeray could not forget that the gentleman was made possible by money, Trollope saw the traditional system of rank as a defense against the encroachment of money-worship." (Gilmour, 152) Not only the rank and appropriate manners, but also the feelings of a gentleman are important values with Trollope. In The Prime Minister, for example, Trollope describes Lopez as follows:

In a sense he was what is called a gentleman. He knew how to speak, and how to look, how to use a knife and a fork, how to dress himself, and how to walk. But he had not the faintest notion of the feelings of a gentleman. (Trollope ch.58)

According to Gilmour "these include the feelings we should expect, such as chivalry, and unselfishness, and also 'manliness', which in Trollope means much what it means elsewhere in the Victorian novel, not hearty muscularity but a balance of masculinity, simplicity and directness of manners and tenderness." (Gilmour, 155) In another work, The Vicar of Bullhampton, Trollope portrays Captain Marrable as a technical gentleman who combines heartlessness with lack of principle and selfishness:

He was good-tempered, well-mannered, sprightly in conversation, and he had not a scruple in the world ... To lie, to steal, - not out of tills or pockets, because he knew the danger; to cheat - not at card-table, because he had never come in the way of learning the lesson; to indulge every passion, though the cost the other might be ruin for life; to know no gods but his bodily senses ... to eat all, and produce nothing; to love no one but himself; to have learned nothing but how to sit at table like a gentleman; to care not at all for his country, or even his profession; to have no creed, no party, no friend, no conscience, to be troubled with nothing that touched his heart; - such had been, was, and was to be life of Colonel Marrable. (Trollope, ch.33)

Captain Marrable has almost all the qualities of a 'fake gentleman' which Trollope believes that a 'true gentleman' should never possess. Gilmour points out that "Captain Marrable is the antithesis of almost everything Trollope believed a gentleman should be. He is heartless, selfish, dishonest, lacking in principle, incapable of loyalty and patriotism." (Gilmour, 156) Showing 'patriotism' to be the crowning quality of Trollope's ideal gentleman, Gilmour concludes his detailed analysis as follows:

To be a gentleman in Trollope it is necessary to show 'manliness' and 'heart', but also to possess the 'hard' quality of principle which his squires have. This is perhaps best summed up, as Ruth Roberts suggested, by the Latin honestum, which Trollope in his Life of Cicero defines as a blend of 'honour' and 'honesty'. Moreover, it is through the destiny of his landed gentleman that Trollope's vision of society is presented. It is not a static vision. What changes, however, is not as 
Dickens and Thackeray, his concept of the gentleman, but his sense of the world in which the gentleman has to live. (Gilmour, 160)

It takes over twenty years for Trollope to write the Barset novels and Palliser series. The Victorian reading public admired the series with the detailed realistic descriptions of social life and vivid psychological portraits of his characters.

\subsection{Conclusions}

The nineteenth century, particularly the Victorian England, saw the rise of the gentleman in two specific ways; first in quantity and then in quality. The increased opportunities in social status in terms of 'wealth' and 'high rank' for the lower and middle classes caused that a lot of commoners gained higher status in English society. Because with the expansion of the British Empire the upper class needed to share the gentlemanly status with more 'ruling class' gentleman. The 'wealthy' gentleman was never rejected but he was easily accepted and welcomed to the upper class. The education of the new apprentice gentleman was a must in two aspects; his manners and intellectual capacity had to be improved. The new 'educated' or 'leveled up' gentleman in his manners, morals and mind power had significant contributions for the English society in two aspects. The integration of the gentleman to his new environment had deep impacts on preventing bloody revolution in Great Britain - as appeared in France due to the huge gaps in life standards between the upper and lower classes -. The educated gentleman functioned like a seed in many fields of life from the rapid development in sciences, technology and industry to his engagement in political arena. His influence was felt even from the reduction of the crimes to the philosophical and sociological developments in Victorian England.

The historian Penelope J. Corfield's research, The Rivals: Landed and Other Gentlemen (1996), has made it obvious that the term 'gentleman' has both social and moral connotations throughout the ages. The important point that "the concept of the gentleman was not merely a social or class designation but there was also a moral component inherent in the concept" (Cody, 1) has also been emphasized by David Cody.

As a result of the development especially in social sciences with the incredible increase in the number of the readers who follow various newspapers, periodicals, and magazines regularly, there used to be hot discussions on defining the characteristics of the gentleman. Significantly in Victorian England, almost every intellectual approached to the idea of the gentleman from various perspectives and it was the high time that the morality of the gentleman gained much importance rather than his wealth or high status in the traditional hierarchy. There was a significant tendency to perceive and describe the gentleman with his 'gentility', 'courtesy' and gentle 'manners'.

Nevertheless, it became hard to distinguish the true gentleman with snobs and devious gentlemen. That's why we have tried to have a close look at his distinctive characteristics that made him a true or a wicked/devious gentleman particularly in Victorian novels. While the true gentleman, playing his role as a leader, a social reformist, a benevolent humanist, a real peacemaker, an activist and a hero, dedicates his own life for his people's pleasure, happiness, comfort and welfare, the wicked/devious gentleman is selfish, never cares the others, and extremely harmful to the people he lives with and the surroundings he lives in like an infectious disease. We have been frequently seeing these types not only fiction but also in the daily life. The importance of unofficial education acquired naturally at home and in the neighborhood and the official education taught at schools, colleges and universities as well as religious preaches at churches, books and means of media has been emphasized in forming the true gentleman.

Thus, first we have attempted to apprehend the Victorian England and Victorian novel in general and then we have tried to distinguish the images of the gentleman in the works of some significant Victorian writers, namely W. Thackeray, C. Dickens and A. Trollope.

\section{References}

[1] Ciugureanu, Adina. Victorian Selves (A Study in Literature of the Victorian age), Constanta: Ovidius University Press, 2008.

[2] Escott, T.H.S. Anthony Trollope - His work, Associates and Literary Originals, New York: John Lane Company, 1913.

[3] Gilmour, Robin. The Idea of the Gentleman in the Victorian Novel, London: Allen \& Unwin, 1981. 
[4] Jr. Payne, L. W. Thackeray, The Sewanee Review, The Johns Hopkins University Press, Vol.8 No.4. 1904.

[5] Mays, Kelly J. "The Publishing World", in Patrick Brantlinger and William B. Thesing (ed.), A Companion to Victorian Literature, Oxford: Blackwell, 2002.

[6] Ray, Gordon N. Thackeray's "Book Of Snobs", University of California Press, Nineteenth-Century Fiction, Vol.10, No.1. 1955.

[7] Trollope, Anthony. Autobiography of Anthony Trollope, New York: George Munro Publisher, 1883.

[8] The Vicar of Bullhampton The Project Gutenburg eBook, 2008.

[9] The Prime Minister The Project Gutenburg eBook, 1999.

[10] Schor, Hilar. "Fiction", in Herbert F. Tucker (ed.), A Companion to Victorian Literature, London: Blackwell, 1999.

\section{$\underline{\text { Internet Resources }}$}

[1] George P. Landow, Victorian and Victorianism, www.victorianweb.org/vn/victor4.html

[2] George P. Landow, Movements and Currents in Nineteenth-Century British Thought, www.victorianwe.org/philosophy/thought.html

[3] G.K. Chesterton, Three main trends of Victorian thought: Utilitarianism, the Oxford Movement, and Romantic Protestantism, www.victorianwe.org/authours/chesterton/victorian2.html

[4] David Cody, The Gentleman, http://www.victorianweb.org/history/gentleman.html

[5] Robert Fletcher, William Makepeace Thackeray: A Brief Biography http://www.victorianweb.org/authors/wmt/wmtbio.html

[6] W.E Henley Thackeray http://www.victorianweb.org/authors/henley/thackeray.html

[7] W. M. Thackeray, Catherina, http://www.victorianweb.org/history/gentleman.html

[8] Merriam Webster Online Dictionary http://www.merriam-webster.com/dictionary/snob 